\title{
Serological Survey of Brucellosis in Camel of Gujarat
}

\author{
H.C. Chauhan ${ }^{1}$, Kirit B. Patel ${ }^{1}$, S.I. Patel ${ }^{1}$, B.K. Patel ${ }^{1}$, B.S. Chandel ${ }^{1}$, A.G. Bhagat ${ }^{1}$, \\ M.V. Patel ${ }^{1}$, S.S. Patel, A.C. Patel ${ }^{1}$, M.D. Shrimali ${ }^{1}$ and Rajeshwari Shome ${ }^{2}$ \\ ${ }^{1}$ Department of Animal Biotechnology and Microbiology, COVSc \& AH, \\ SDAU, Sardarkrushinagar-385006, Gujarat, India \\ ${ }^{2}$ NIVEDI (ICAR), Bengaluru, India \\ *Corresponding author
}

\begin{tabular}{|c|c|}
\hline & A B S T R A C T \\
\hline & \multirow{4}{*}{$\begin{array}{l}\text { Brucellosis is a zoonotic bacterial disease of ruminants and also reported from camel. } \\
\text { Camels are one of the most important sources of livelihood for the nomadic population of } \\
\text { Gujarat. There are limited published information regarding the sero-epidemiology of camel } \\
\text { brucellosis in Gujarat. Therefore, present study was aim to determine the brucella specific } \\
\text { antibodies in camel from three camel rearing districts of Gujarat using RBPT, i-ELISA and } \\
\text { MRT. On screening of } 352 \text { serum samples, } 41(11.64 \%) \text { and } 16(4.54 \%) \text { samples found } \\
\text { positive by RBPT and i-ELISA, respectively. } 8(15.38 \%) \text { samples of milk found positive } \\
\text { from total } 52 \text { samples by MRT. It was also revealed from the study that the female camel } \\
\text { have high seroprevalence of brucellosis than male. Prevalence of brucellosis among the } \\
\text { camels of various districts of north Gujarat indicates that the disease is endemic and may } \\
\text { act as the source of infection for other susceptible animals including human beings. }\end{array}$} \\
\hline $\begin{array}{l}\text { Brucellosis, Camel, } \\
\text { RBPT, MRT, } \\
\text { i-ELISA, PCR. }\end{array}$ & \\
\hline Arti & \\
\hline $\begin{array}{l}17 \\
\text { nline: }\end{array}$ & \\
\hline
\end{tabular}

\section{Introduction}

Brucellosis is caused by various species of the genus Brucella, which is the second most widely spread zoonosis worldwide (Dawood, 2008). It is one of the infectious diseases, which poses major constraint for animal production. The disease is an important public health problem in many parts of the world including India (Pal, 2007; Hadush and Pal, 2013). Brucellosis is burning problem in Gujarat, where cases of human brucellosis are reported along with high sero-prevalence in animals.

Brucella can affect almost all domestic species and cross transmission can occur between cattle, sheep, goat, camel and other species (Ghanem et al., 2009). Brucellosis was reported in camels as early as 1931 (Solonitsuin, 1949); since then, the disease has been reported from all camel-keeping countries (Gwida et al., 2012). Camels are frequently infected with Brucella organisms, especially when they are in contact with infected large and small ruminants (FAO/WHO, 1986; Radwan et al., 1992). Brucellosis is characterized by abortion and birth of non-visible offspring in females; orchitis and epididymitis in males (Radostits et al., 2007). The disease is also associated with infertility and prolonged calving intervals and has considerable impact on camel production. It may also causes, chronic inflammation of joints, tendon sheath and synovial bursa especially at the carpus (Abbas 
and Agab, 2002). Serological evidence for Brucella infection in camels has been reported from Asia and Africa (Dawood, 2008). There are many factors that can affect the prevalence of brucellosis in various species of livestock. Prevalence may vary according to climatic conditions, geography, species, sex, age and diagnostic tests used (Gul and Khan, 2007). Camels are not known to be primary host for any of Brucella organisms but they are susceptible to both $B$. abortus and B. melitensis (Musa and Shigidi, 2001). The relation between Brucella infection and abortion in camels has been recorded (Al-Majali et al., 2008; Higgins, 1986, Agab and Abbas, 1999). Both Brucella abortus and Brucella melitenis have been isolated from fetuses, genital discharges, urine and milk (FAO/WHO, 1986).

The disease has been reported from various species in different parts of India. But, there are limited published reports of brucellosis in camel and only a few reports from Gujarat. Camel brucellosis has not received proper attention from researchers and scientists. Therefore, present study was planned for the detection of Brucella antibody from camels and overall seroprevalence of camel brucellosis was determined using RBPT, iELISA and MRT.

\section{Materials and Methods}

The present study was conducted during the period from June to December 2014. A total of 352 serum samples were collected from camel of rural areas and organized farms belongs to three semi-arid districts (Banaskantha, Patan and Kutch) of north Gujarat, having high camel population. Blood samples were collected in tube containing clot activator (Greiner bio-one, Austria) aseptically from the jugular vein and allowed to clot. Serum was collected and stored at $20^{\circ} \mathrm{C}$ till further use.
All the collected serum samples were screened for antibodies against Brucella by the Rose Bengal Plate Test (RBPT) and the Indirect Enzyme Linked Immunosorbant Assay (i-ELISA). The RBPT antigen was procured from the Institute of Animal Health and Veterinary Biologicals (IAH and VB), Hebbal, Bangalore, Karnataka. RBPT was performed according to manufacturer's instructions. Definite clumping/agglutination was considered as positive reaction; whereas, no clumping/agglutination was considered as negative. Indirect ELISA kit was procured from National institute of Veterinary Epidemiology and Disease informatics (NIVEDI) Bangalore, and used as per manufacturer's protocols. The kit detects the antibodies against Brucella lipopolysaccharide (LPS) in serum samples of B. aborus and B. melitensis.

Milk ring test (MRT)/Aborts Bang ring test (ABR) was performed using colored antigen procured from Institute of Animal Health and Veterinary Biologicals (IAH and VB), Hebbal, Bangalore, Karnataka. In brief, MRT antigen was brought to room temperature before use. $2 \mathrm{ml}$ of milk sample was taken in test tube. Then, 2 drops of MRT/ABR antigen was added, and gently mixed. The tubes were incubated at $37^{\circ} \mathrm{C}$ for one hour. Then kept at room temperature for $30 \mathrm{~min}$. and results were recorded. A sample which shows colored ring at the surface was considered as positive (Fig. 2).

The genomic DNA from 22 serum samples was extracted using DNeasy blood and tissue kit (QiAgen, USA) and subjected for Brucella detection using primer pair (Table 1).

PCR reaction mixture was prepared in $25 \mu 1$ volume consisting of $12.5 \mu \mathrm{l} 2 \mathrm{x}$ PCR-MasterMix (Fermentas), $1 \mu \mathrm{l}$ of forward and reverse primers each $(12 \mathrm{pmol} / \mu \mathrm{l}), 10 \mu \mathrm{l}$ of DNA template and nuclease free water. PCR 
amplified product was checked by running samples over $1.5 \%$ agarose gel.

\section{Results and Discussion}

According to the Food and Agriculture Organization (FAO), the World Health Organization (WHO) and the World Organization for Animal Health (OIE) brucellosis is still one of the most important and widespread zoonoses in the world (Young, 1995). It has high public health significance and may poses threat to all human as diseases may transmit through consumption of raw and under cooked milk and milk products (Schelling et al., 2003).

The present study was aimed to study the prevalence of brucellosis in camel. Total 352 serum samples were screened, 41(11.64\%) were found positive by RBPT (Table 2). In accordance to the present finding, Zewold and Haileselassie (2012) reported 11.90 percent seroprevelence by RBPT (Fig. 1). However, in-contrast to present findings, lower rate of seroprevalence was reported (Ghanem et al., 2009; Shome et al., 2013); whereas, Dawood (2008) reported higher rate $(14.2 \%)$ of seroprevelence of Brucella antibody in camel by RBPT. In indirect ELISA, 16 (04.54\%) were found positive (Table 2). In accordance to the present findings, Shome et al., (2013) reported 4.9 percent seroprevelence using iELISA. However, in contrast to present findings, Ghanem et al., (2009) reported lower rate of 3.1 percent seroprevalence. The difference in seroprevalence might be due to differences in sample size, tests used, management condition, herd size or due difference in seroprevalence in the two study areas. According to Radiostits et al., (2007), herd size and management condition determine rate of transmission of Brucella infection in different study areas. In district wise analysis of results, it was found that the Banakantha, Patan and Kutch have 16.89, 11.57, 02.41 and 5.40, 05.78, $01.20 \%$ seroprevalence using RBPT and i-ELISA, respectively (Table 2 and Fig. 3).

In male camels, seroprevalence reported as 09.45 and 01.35 percent by RBPT and iELISA, respectively. Whereas, in case of female, it was 12.23 and 05.38 per cent by RBPT and i-ELISA, respectively (Table 2). The higher seroprevalence of brucellosis in female camels might be attributed to the fact that female animals remained in the breeding herds for a longer period of time than male animals that are being culled from time to time and sold to meet pastoralists' financial needs. According to Radostitis et al., (2007), physiological and behavioral differences between male and female animals involve in the variation in sex susceptibly for brucellosis. Brucella infection is more common in female camels may be associated to erythritol (Gyles et al., 2004).

Table.1 Primer pair for Brucella detection

\begin{tabular}{|c|c|c|c|c|c|}
\hline $\begin{array}{l}\text { Sr. } \\
\text { No }\end{array}$ & Primer & $\begin{array}{l}\text { Forward } \\
\text { /Reverse }\end{array}$ & $\begin{array}{c}\text { Sequence } \\
\left(5^{\prime}-3^{\prime}\right)\end{array}$ & $\begin{array}{l}\text { Product } \\
\text { size (bp) }\end{array}$ & Reference \\
\hline 1. & B4 & Forward & $\begin{array}{l}\text { TGG CTC GGT TGC CAA TAT } \\
\text { CAA }\end{array}$ & \multirow[t]{2}{*}{223} & \multirow{2}{*}{$\begin{array}{l}\text { Bailly et al. } \\
\quad \text { (1992) }\end{array}$} \\
\hline 2. & B5 & Reverse & $\begin{array}{l}\text { CGC GCT TGC CTT TCA GGT } \\
\text { CTG }\end{array}$ & & \\
\hline
\end{tabular}


Table.2 Seroprevalence of Brucella in camel by RBPT and i-ELISA

\begin{tabular}{|c|c|c|c|c|c|}
\hline \multirow[t]{2}{*}{ Attributes: } & \multirow{2}{*}{$\begin{array}{l}\text { Sample } \\
\text { tested }\end{array}$} & \multicolumn{4}{|c|}{ No. of sample found positive } \\
\hline & & RBPT & $\%$ & i-ELISA & $\%$ \\
\hline \multicolumn{6}{|l|}{ Districtswise Seroprevalence: } \\
\hline Banaskantha & 148 & 25 & 16.89 & 08 & 05.40 \\
\hline Patan & 121 & 14 & 11.57 & 07 & 05.78 \\
\hline Kutch & 83 & 02 & 02.41 & 01 & 01.20 \\
\hline Total & 352 & 41 & 11.64 & 16 & 04.54 \\
\hline \multicolumn{6}{|l|}{ Sexwise Seroprevalence: } \\
\hline Male & 74 & 07 & 09.45 & 01 & 01.35 \\
\hline Female & 278 & 34 & 12.23 & 15 & 05.38 \\
\hline Total & 352 & 41 & 11.64 & 16 & 04.54 \\
\hline
\end{tabular}

Table.3 Seroprevalence of Brucella in camel by MRT

\begin{tabular}{|l|c|c|}
\hline \multicolumn{1}{|c|}{ Districts } & Sample tested & MRT (\%) positive \\
\hline Banaskantha & 22 & $05(22.73)$ \\
\hline Patan & 19 & $03(15.79)$ \\
\hline Kutch & 11 & $00(0.0)$ \\
\hline & $\mathbf{5 2}$ & $\mathbf{0 8}(\mathbf{1 5 . 3 8})$ \\
\hline
\end{tabular}

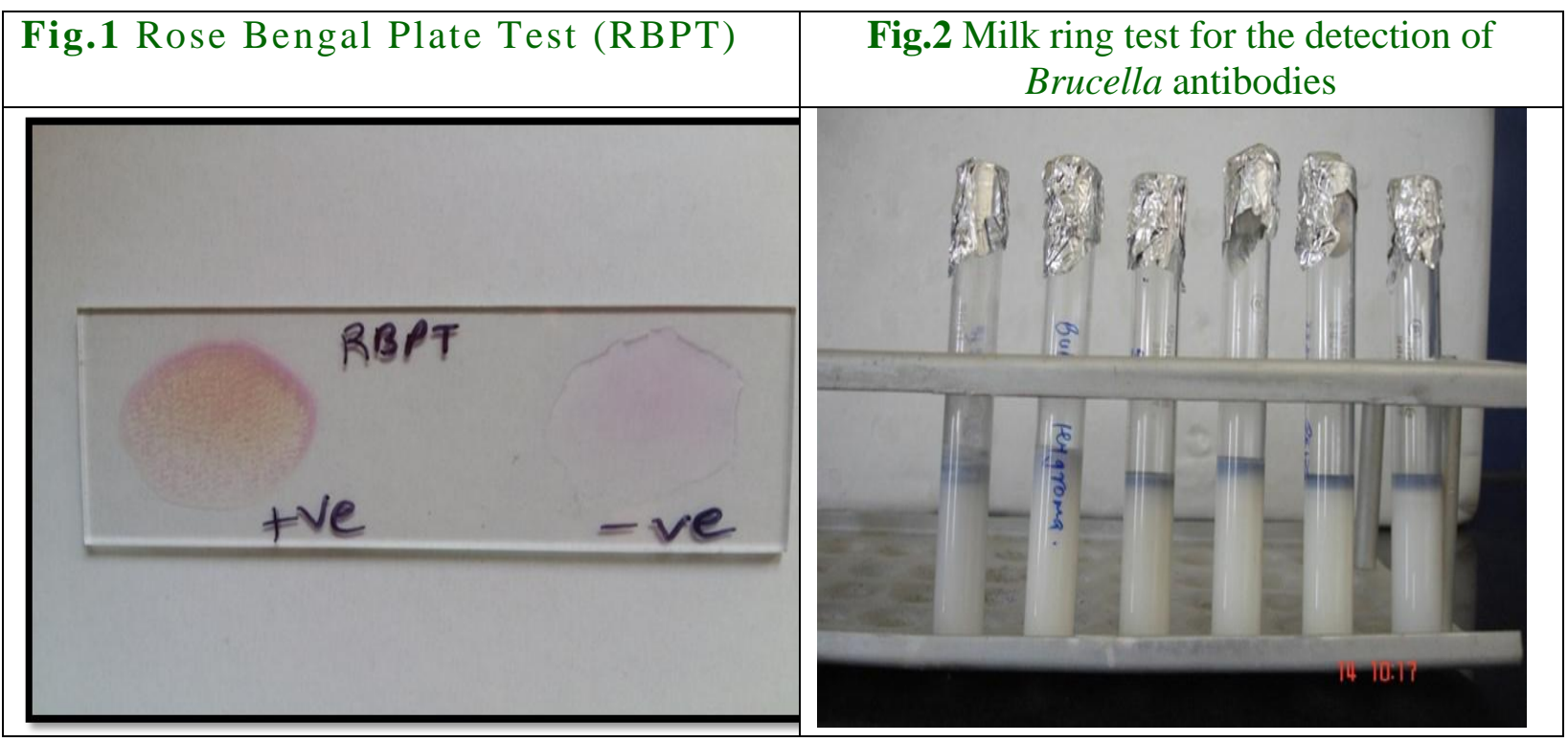


Fig.3 Microtiter ELISA plate showing result of i-ELISA

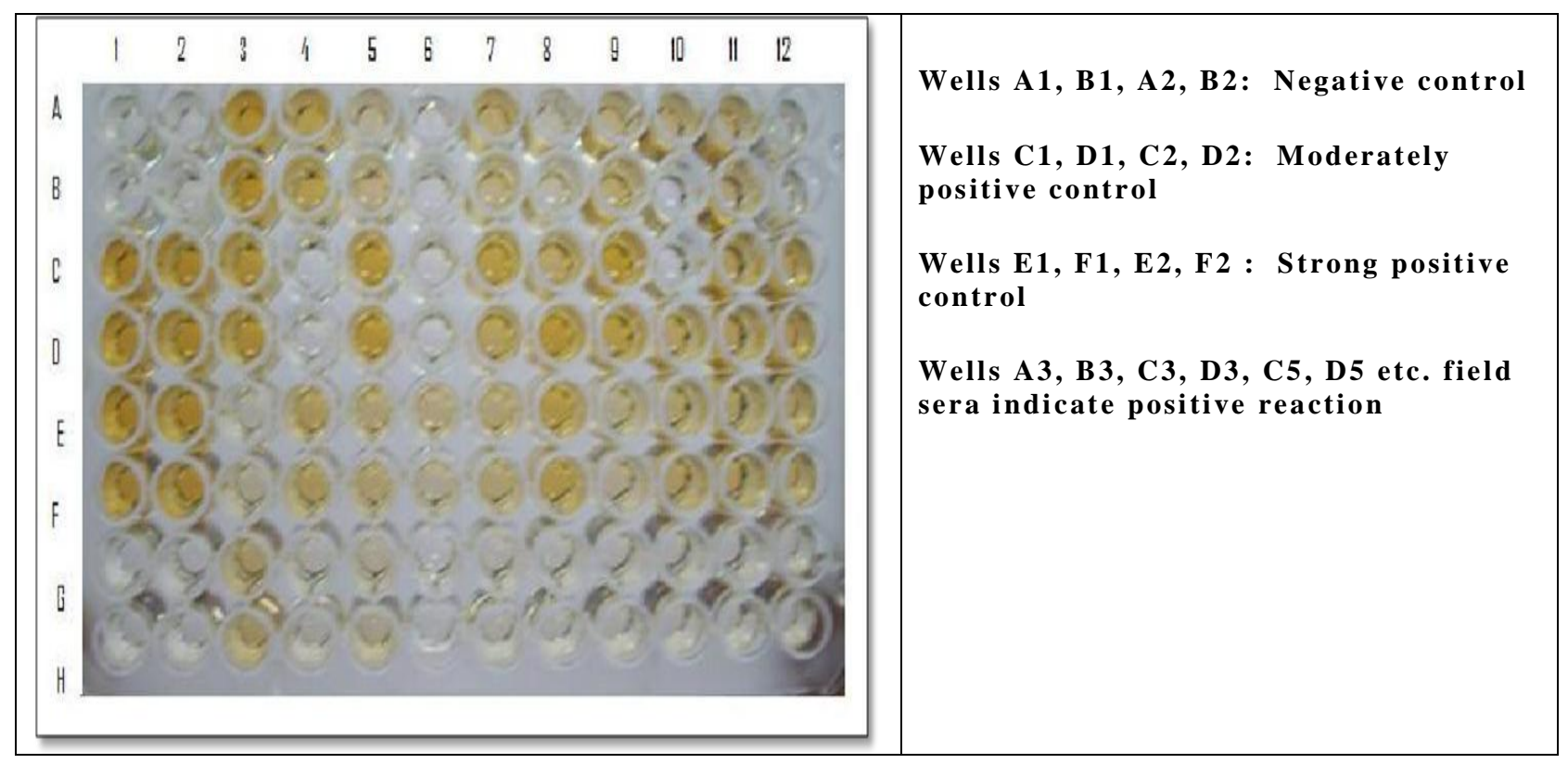

A total of fifty two (52) camel milk samples were tested using the Milk Ring Test (MRT) and eight (08) samples (15.38\%) were found positive for the presence of Brucella specific antibodies (Table 3). Similar observation was also reported by Wanjohi et al., (2012). High prevalence in the present study might be due to the collection of samples from the endemic population and have history of abortion. Moreover, rearing of multispecies in same herd may leads to close contact of animals, which may facilitate the exchange of various pathogenic microorganisms. In the present study area, it was observed that the camels were reared with small ruminants like sheep and goats which might be the possible source of infection for camel. Which may be the possible source of abortion in camels and similar observations were reported from different places (Gameel et al., 1993; Radwan et al., 1995).

Several studies have documented the detection of Brucella specific genome from the serum samples using PCR (Shome et al., 2013; Brown et al., 1995; Murdoch et al., 1996; Bougnoux et al., 1999; Kawamura et al., 1999). The use of serum instead of wholeblood samples offers several advantages for nucleic acid amplification. In the present study, an attempt was made to detect the Brucella specific antigen from the serum samples using PCR. But it not observed that the specific amplification in any samples. This might be possible due to small sample size and time of sample collection.

The present study may be concluded that brucellosis is prevalent in major camel rearing districts of Gujarat. Therefore, individuals associated with camel rearing and managements need to be aware regarding the possible source of Brucella infection. Therefore, it's worth to include this species in state/national Brucella control programme, which may help to improve the production and minimize risk of transmission to humans.

\section{Acknowledgement}

Thanks are extended to the Department of Biotechnology, Govt. of India for financial support under DBT network project on Brucellosis and Project Coordinator, Project Monitoring unit, NIVEDI, Bengaluru for 
monitoring the project work. Thanks are also due to Dean, College of Veterinary Science and $\mathrm{AH}$ and Director of Research SDAU, Sardarkrushi nagar for necessary facilities to carry out this work.

\section{References}

Abbas, B. and Agab, H. 2002. A review of camel brucellosis. Preventive Vet. Med., 55: 47-56.

Agab, H. and Abbas, B. 1999. Epidemiological studies on camel diseases in eastern Sudan, Wld. Anim. Rev., 92: 42-51.

Al-Majali, A.M., Al-Qudah, K.M., Al-Tarazi, Y.H and Al-Rawashdeh, O.F. 2008. Risk factors associated with camel brucellosis in Jordan. Trop. Anim. Health Prod., 40: 193-200.

Bailey, G.G., Krahn, J.B., Drasar, B.S., Stoker, N.G. 1992. Detection of Brucella melitensis and Brucella abortus by DNA amplification. J. Trop. Med. Hyg., 95: 271-275.

Bougnoux, M.E., Dupont, C., Mateo, J., Saulnier, P., Faivre V., Payen, D., Nicolas-Chanoine M.H. 1999. Serum is more suitable than whole blood for diagnosis of systemic Candidiasis by nested PCR. J. Med. Microbiol., 37: 925.

Brown, P.D., Gravenkamp, C., Carrington, D.G., Van de Kemp, H., Harrrtskeerl, R.A., Edwards, C.N., Everard, C.O., Terpstra, W.J. and Levett, P.N. 1995. Evaluation of Polymerase chain reaction by early diagnosis of Leptospirosis. $J$. Med. Microbiol., 43: 110.

Dawood, H.A. 2008. Brucellosis in camels (Camelusdromedorius) in the south province of Jordan. Am. J. Agric. Biol. Sci., 3: 623-626

FAO/WHO. 1986. Joint FAO/WHO Expert Committee on brucellosis. Sixth Report. Technical Report Series No. 740. World
Health Organization, Geneva.

Gameel, M.A., Mohamed, O.S., Mustafa, A.A. and Azwai, M.S. 1993. Prevalence of camel brucellosis in Libya. Trop. Animal Health and Production, 25: 9193.

Ghanem, Y.M., El-Khodery, S.A., Saad, A.A., Abdelkader, A.H., Heybe, A. and Musse, Y.A. 2009. Seroprevalance of camel brucellosis (Camelisdromedarus) in Somaliland. Trop. Anim. Health Prod., 41: 1779-1786.

Gul, S.T. and Khan, A. 2007. Epidemiology and Epizootology of Bbrucellosis: A Review. Pak. Vet. J., 27: 145-151.

Gwida, M., Gohary, A.E., Melzer, F., Khan, I., Rösler, U. and Neubauer, H. 2012. Brucellosis in camels. Res. Vet. Sci., 2: 351-355

Gyles, C.L., Prescott, F.J, Songer, G.J. and Thoen, O.C. 2004. Themes in Bacterial Pathogenic Mechanisms. In: Pathogenesis of Bacterial Infections in Animals. 3 ed. Eds., Australia; Blackwell Publishing. 309-315.

Hadush, A. and Pal, M. 2013. Brucellosis An infectious re-emerging bacterial zoonosis of global importance. Int. J. Livest. Res., 3: 28-34.

Higgins, A. 1986. The Camel in Heath and Disese, Bailliere Tindall, London.

Kawamura, S., Maesaki, S., Noda, T., Hirakata, Y., Tomono, K., Tashiro, T. and Kohno, S. 1999.Comparison between PCR and detection of antigen in sera for diagnosis of pulmonary aspergillosis. J. Clin. Microbiol., 37: 218-220.

Murdoch, D.R., Walford, E.J., Jennings, L.C., Light, G.J., Schousboe, M.I., Chereshsky, A.Y., Chambers, S.T. and Town, G.I. 1996. Use of the polymerase chain reaction to detect Legionella DNA in urine and serum samples from patients with pneumonia. Clin. Infect. Dis., 23: 475. 
Musa, M.T. and Shigidi, M.T.A. 2001. Brucellosis in camels in intensive animal breeding areas of Sudan: Implications in abortions and early-life infection. Revue Elev. Med. Vet. Pays. Trop., 54: 11-15

Pal, M. 2007. Zoonoses. 2nd Ed. Satyam publishers. Jaipur, India, 98-99.

Radostits, O.M., Gay, C., Blood, D.C. and Hinchclift, K.W. 2007. Disease associated with helminthes parasite. In: veterinary medicine, a text book of the disease of cattle, sheep, goat, pigs and horses. 10th ed. London: Bailliere, Tindall, UK, 984-988.

Radwan, A.I., Bekairi, S.J. and Prasad, P.V.S. 1992. Serological and bacteriological study of brucellosis in camels in central Saudi Arabia. Rev. Sci. Tech. OIE, 11: 837-844.

Radwan, A.I., Bekairi, S.J., Mukayel, A.A., Albokmy, A.M., Prasad, P.V.S, Azar, F.N. and Coloyan, E.R. 1995. Control of Brucella melitensis infection in large camel herd in Saudi Arabia using antibiotherapy and vaccination with Rev.1 vaccine. Revue Scientifique et Technique de l Office International des Epizooties 14:719-732.
Schelling, E., Diguimbaye, C., Daoud, S., Nicolet J., Tanner, M. and Zinsstag, J. 2003. Brucellosis and Q-fever seroprevalences of nomadicpastoralists and their livestock in Chad. Prev. Vet. Med., 4: 279-293.

Shome, R., Gupta, V.K., Bhardwaj, B., Shome, B.R., Nagalingam, M. and Rahman, H. 2013. A report of seroprevalence of camel brucellosis in India. J. Camel Practice and Res., 20(2): 183-186.

Solonitsuin, M.O. 1949. Brucellosis in camels. Veterinaria, Moscow 26: 1621.

Wanjohi, M., Gitao, C.G., Bebora, L. 2012. The prevalence of Brucella spp in camel milk marketed from north eastern province. Res. Opin. Anim. Vet. Sci., 2(7): 425-434.

Young, E.J. 1995. An overview of human brucellosis. Clin. Infect. Dis., 2: 90-283.

Zewold, S.W., Haileselassie, M. 2012. Seroprevalence of Brucella infection in camel and its public health significance in selected districts of afar region, Ethiopia. J. Environ. Occu. Sci., 1(2): 91-98.

\section{How to cite this article:}

Chauhan, H.C., Kirit B. Patel, S.I. Patel, B.K. Patel, B.S. Chandel, A.G. Bhagat, M.V. Patel, S.S. Patel, A.C. Patel, M.D. Shrimali and Rajeshwari Shome. 2017. Serological Survey of Brucellosis in Camel of Gujarat. Int.J.Curr.Microbiol.App.Sci. 6(4): 1815-1821. doi: https://doi.org/10.20546/ijcmas.2017.604.217 